TEHNIČKE ZNANOSTI 



\title{
A VENTILATION SYSTEM IN THE PORTUGUESE MINING COMPANY ALMINA ${ }^{3}$
}

\begin{abstract}
In order to work in a mine, two main requirements have to be met - roof and ground support and ventilation support. Roof and ground support is important because in case of an accident, workers can, without problems, evacuate the mine. However, besides roof and ground support, in order to fulfill normal working conditions inside the mine, a ventilation system is a valuable and key part of the working process. This paper represents the ventilation system in the Portuguese mining company Almina. It encompasses a ventilation system in the underground and on the surface. The main problems of a ventilation system are discussed, as well as a short scheme offresh air inhalation and stale air exhalation outside the mine. The result of the paper was to figure out how the ventilation system operates in practice. The aim of the paper was to present a real ventilation system by taking into consideration the fact that there are no mining companies in the Republic of Croatia where people could learn facts of mining companies and ventilation systems, which is very important in case of dangerous situations.
\end{abstract}

Keywords: mine, safety inside the mine, ventilation system, ventilation problems, working conditions

\section{INTRODUCTION}

A ventilation system must supply every workplace inside the mine where miners operate. The main fan, which is on the surface, brings fresh air to the mine's interior, and underground fresh air stations transport fresh air to working locations. These two elements must be balanced for effective work conditions; otherwise a system can face problems. The problems of the ventilation system can be unnecessary air supply, air leak and a blocked main tube, which is a connector between the main fan and a fresh air station. This could be resolved by controlling and examining working conditions inside the mine regularly. The ventilation system is a complex part of every mine company, and it represents the main requirement for normal working conditions.

\section{VENTILATION OF THE MINES}

Deep mines require elaborate, mechanically-operated systems for maintaining air supply in healthy conditions. Lives of those working in or traveling through such areas depend upon a constant supply of fresh air. Not only must the systems used be highly efficient, but there should be the

Bacc. ing. sec., student, Polytechnic of Rijeka, Vukovarska 58, Rijeka, Croatia. E-mail: mario.milicic.1993@gmail.com

M. Eng., Lecturer, Polytechnic of Rijeka, Vukovarska 58, Rijeka, Croatia. E-mail: kristina.dundovic@veleri.hr

Received: 15 January 2017; Accepted: 15 February 2017 
provision for emergencies in case of failure of the apparatus in operation (http://www.infoplease. com/).

Ventilation is a basic part of all underground mine operations. It is built in order to introduce fresh, cool air to the workplace and to remove stale, affected air. A mine ventilation system includes:

- fans;

- airways;

- control devices to direct or restrict air flow;

- cooling and filtering air;

- systems for monitoring air quality and quantity.

Underground mine ventilation is required to remove hazardous substances, control the thermal environment, and provide oxygen for humans and engine combustion.

A mine ventilation system can be homotropal when the movement of fragmented ore is in the same direction as the fresh air, whereas an antitropal ventilation system is one where the movement of fragmented ore is opposite to the movement of fresh air. Also, there is ascentional ventilation, which takes the advantage of the tendency of warm air to move upwards through inclined workings and utilizing natural ventilation effects. On the other hand, descentional ventilation system is employed where the air can enter the mine at a higher elevation where it is cooler and drier (http://www.undergroundcoal.com.au/).

Picture 1. A basic ventilation system underground where $D$ is a ventilation door or airlock, $R$ is a mine regulator and 1,2,3 are working places with a surface exhaust fan

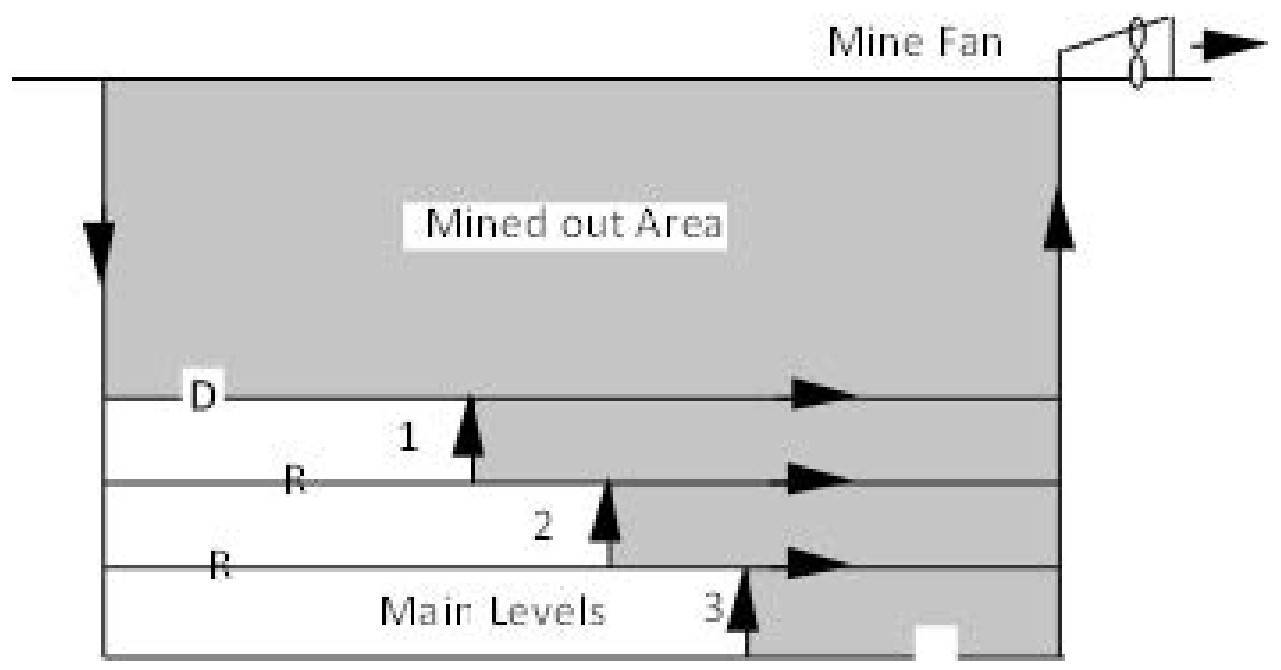

Source: http://miningquiz.com/pdf/Ventilation/Lab8-Systems.pdf 
A well-designed and properly implemented ventilation system will provide beneficial physiological and psychological side effects that enhance employee safety, comfort, health, and morale.

In planning a ventilation system, the quantity of air will be necessary to circulate because of all health and safety standards, which must be decided at the outset. Once the quantity required has been fixed, the correct size of shafts, number of airways, and fans can be determined.

As fresh air enters the system through the intake airshaft(s) or other connections to the surface, it flows along intake airways to the working areas where the majority of pollutants are added to the air. These include dust and a combination of many other potential hazards, such as toxic or flammable gases, heat, humidity, and radiation. The contaminated air passes back through the system along return airways. In most cases, the concentration of contaminants is not allowed to exceed mandatory threshold limits imposed by law. The return (or contaminated, exhausted) air eventually passes back to the surface via return airshaft(s), or through inclined or level drifts. (http://web.mst.edu/)

For producing a proper ventilation design the following building system should be followed:

- $\quad$ select main ventilation inlets and outlets;

- determine airflow requirements;

- specify fan locations;

- determine air flow resistance for all branches;

- $\quad$ build and run a computer model of the mine ventilation system;

- adjust a system layout, design parameters, and equipment operating characteristics and rerun computer code until a viable system results;

- review the plan with operating personnel.

\section{OXYGEN LEVEL}

Oxygen is the most important gas inside the mine. On the surface level there is around $21 \%$ of oxygen in the atmosphere (depending on the place on the Earth). Below the surface the level of oxygen is getting lower. Due to that, there is a need to take care of the issue of working beneath the surface in normal conditions.

Unlike other gases that will be considered, under normal conditions, oxygen is not contaminated. It is the only gas that must be treated as a high concentrated gas inside mines. Processes in which the oxygen content of air is reduced as it travels through a mine are many and they are usually associated with the presence of one or more other gases. These processes include dilution with other gases, high-temperature oxidation such as internal-combustion engines and open flames, and low-temperature oxidation of wood and minerals. The influence of the oxygen-deficient environment varies from individual to individual and with the length of exposure. Therefore, the following effects have been observed (Hartman et al., 1997): 
Table 1. People's effect with presence of oxygen

\begin{tabular}{|c|l|}
\hline \% Oxygen in Air & \multicolumn{1}{|c|}{ Effect } \\
\hline 17 & Faster, deep breathing \\
\hline 15 & Dizziness, buzzing in ears, rapid heartbeat \\
\hline 13 & Possible loss of consciousness with prolonged exposure \\
\hline 9 & Fainting, unconsciousness \\
\hline 7 & Life endangerment \\
\hline 6 & Convulsive movements. death \\
\hline
\end{tabular}

Source: Hartman et al. (1997)

Oxygen level should be higher than $17 \%$ in the air all the time, but the best solution is $21 \%$. However, sometimes this is not possible and it can be $\geq 17 \%$. In that case people who are inside the mane have faster and deeper breathing. From 15-13\% they can have rapid heartbeat or dizziness ot there is even a possibility of losing consciousness with prolonged exposure. In cases where oxygen level is equal or lower than $9 \%$, this may lead to unconsciousness, endangerment or death. Given the previous reasons the level of oxygen is important in mines.

\section{HAZARDS IN MINES PREVENTED BY VENTILATION}

Mine ventilation controls the following hazards:

- $\quad$ oxygen content;

- toxic and asphyxiant gases;

- flammable gases;

- airborne dust;

- fumes;

- products of combustion;

- humidity;

- temperature;

- naturally occurring radioactive materials (NORM).

Any other hazard at the mining operation identified by the site senior executive as a hazard that could create a risk of multiple fatalities in a single accident, or a series of recurring accidents at the mining operation.

The Ventilation Control Plan minimizes the risks of these hazards by providing systems, processes and procedures to establish and maintain a safe level of air in an underground mine. Effective risk control at a mine requires the mine operator to follow a Risk Management Process. It sets out requirements for: 
- roles, responsibilities and competencies;

- design and planning;

- inspection, measuring and monitoring;

- fans;

- ventilation control devices;

- auditing and review;

- reference to standards.

\section{PORTUGUESE MINING COMPANY ALMINA}

Almina is a Portuguese mining company whose social goal is extracting and valuing of pyrites, sulphides and other ores, the trade, transport of the products and derivatives and the research, purchase and development of technological methods for its mining activities.

The Concession, that is, the Mining Park of Aljustrel, was given by the Portuguese Government and at present there are five hundred people working in the extraction of ore and in the production of copper (Cu) concentrates. Due to this reason, it has an important role in the region's economy.

Almina respects all the Environmental Protection Norms applying these to the most modern available technologies (http://www.almina.pt/).

\section{1 ALMINA'S PRODUCTION SYSTEM}

Almina is a Portuguese mining company which produces copper $(\mathrm{Cu})$. From the beginning until the end of the process in Almina, there are nine phases. For every phase an educated and specialized group of people have different tasks. The phases are the following:

1. drilling the rocks;

2. placing explosives inside holes in rocks;

3. extracting;

4. crushing;

5. transporting to surface;

6. grinding;

7. flotation;

8. filtration;

9. final product.

Drilling the rocks in Almina is the first process of extraction. The EPDM - Drilling Company and Mining Development is doing this part of the job. Making holes can be vertical and horizontal and it depends on the position of rock, extraction, etc.

After making holes inside of the rock, specialized workers put explosive from the company Orica. When explosive is installed, the next step is detonation. During the detonation, everybody must 
be outside of the mine for a few hours. During these hours, workers wait for air to clean inside of the mine.

After detonation, workers do the extraction by 14 or 60 tonne trucks. These trucks have a priority in transport because they are big and heavy and also if they stop, the production stops.

Trucks are going to the underground space where machines do the process of crushing. The process is based on rotation drum, which makes smaller pieces of rocks.

By using vibration strips, rocks are transported to the surface.

The process of grinding takes place outside, on the surface, in the main production part of the company. In that process, small rocks become even smaller.

Flotation and filtration are final process in copper-making. In these processes, copper is transformed into dust.

Picture 2. Logo of Almina's company

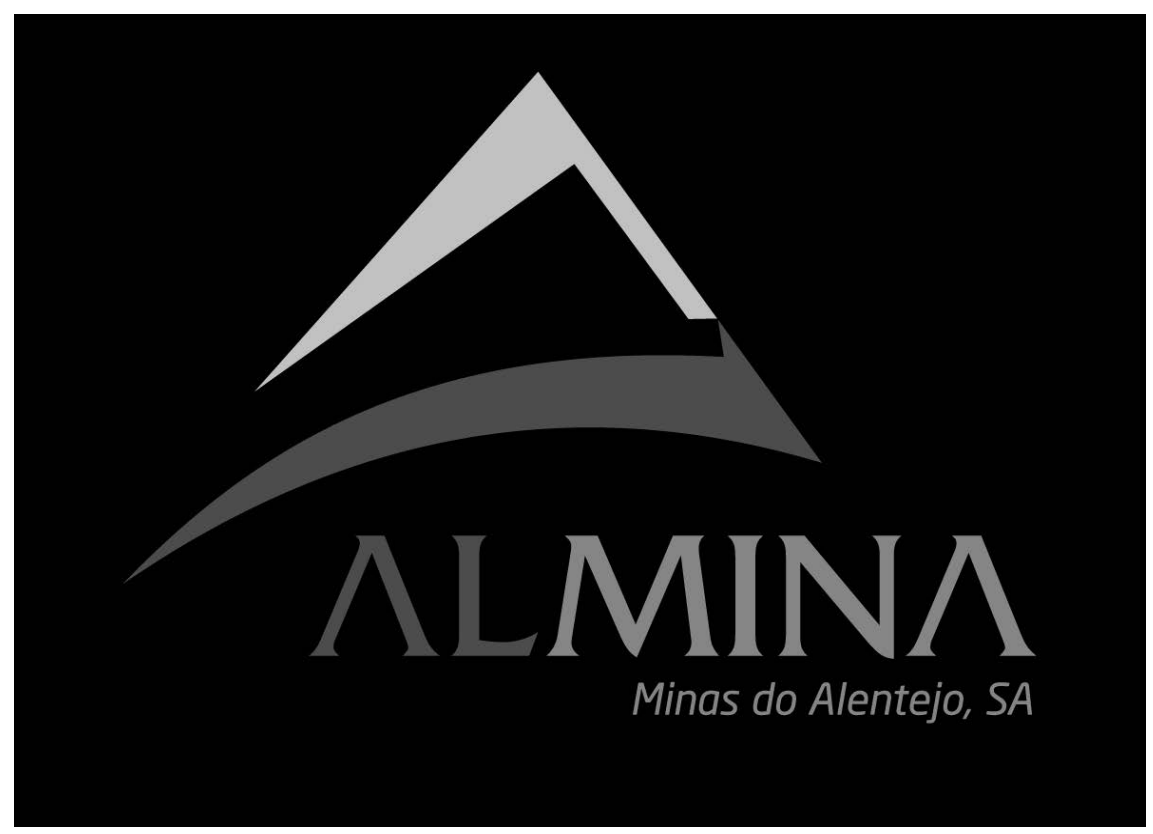

Source: Almina's intern document Plano de Segurança e Saúde

\section{INTRODUCTION INTO THE VENTILATION SYSTEM IN ALMINA}

The ventilation system in Almina consists of two parts: a ventilation system on the surface and a ventilation system under the ground. Both systems have roles and tasks which they need to accomplish during the working day. 
On the surface Almina has a few big fans which inhale fresh air inside of the mine. Fresh air is transported thought predicted spots where workers and workplaces are and it is the role of underground ventilation.

A connection between surface and underground ventilation is one big main tube. Also, this tube is an emergency exit if there is a dangerous situation inside of the mine. In the next picture, there is an explanation of the ventilation system of Almina's mines.

Picture 3. Ventilation system of Almina's company

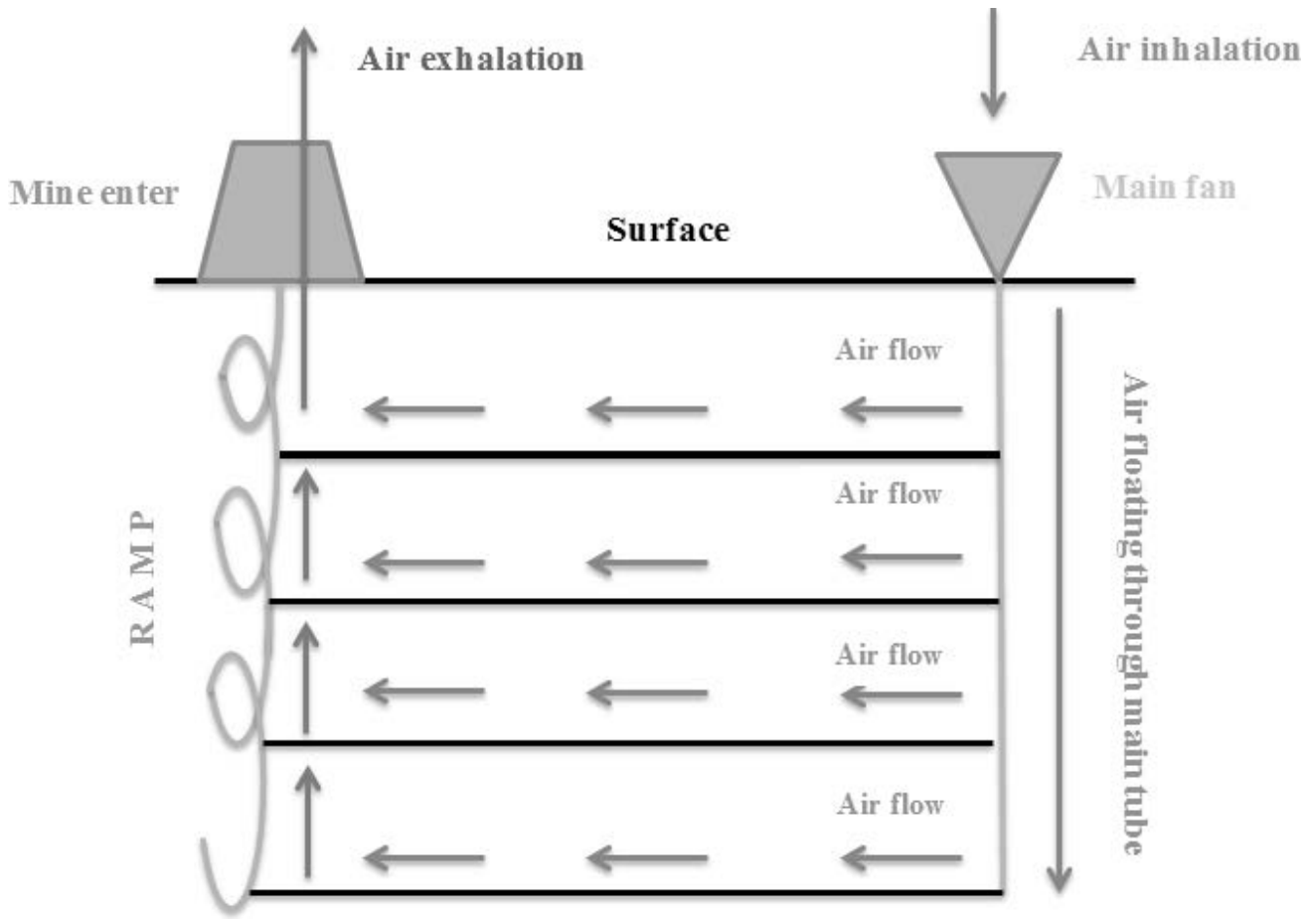

Source: Author's production 


\section{1 A ventilation system on the surface}

Like in every mine company, ventilation is a part of one of the most important processes. Ventilation in Almina's company is based on outside inhalation including 8 main fans (CPV $0-7$ ). These fans have different inhalation power and different input places. Stale air is going out thought the "ramp" by the "main exit doors". Ramp is the main road which connects surface with other paths inside of the mine.

Picture 4. A display of the main fan CPV 1 in Almina's company

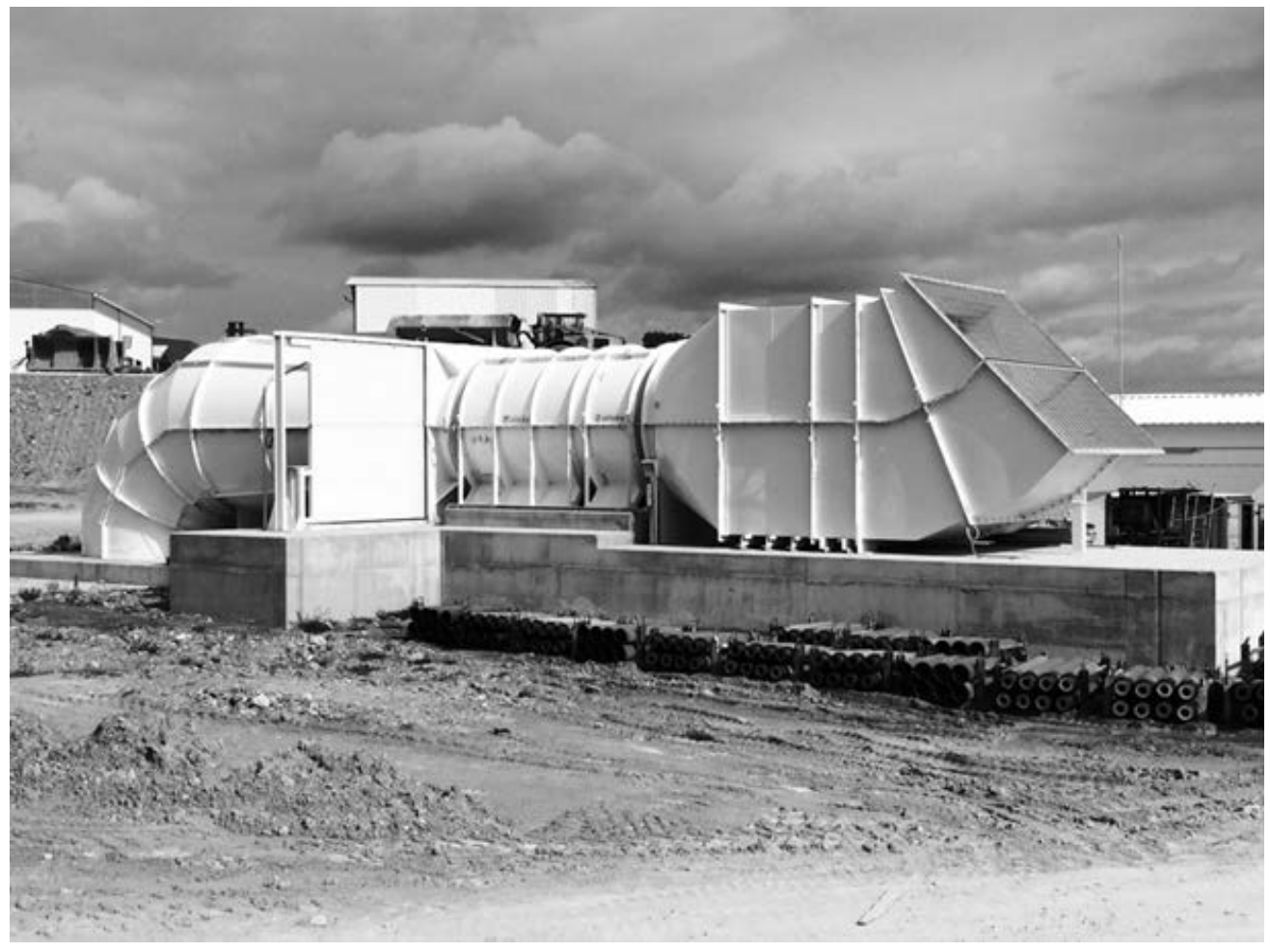

Source: Almina's intern document Plano de Segurança e Saúde

Every fan on the surface has different characteristics. This depends on the spot where air needs to be supplied, how many people will work on that place and if there is any support by other fans. Fans also need to be in function every working day. If they stop working due to some reason, people inside of the mine need to be evacuated because of the limited amount of fresh air.

\section{2 Ventilation system under the ground}

Near the surface a ramp can be without ventilation because there is still fresh air from the surface atmosphere. Deeper under the ground, ventilation must exist through the entire ramp. Also, through the ramp, ventilation must be on one side and electrical cables and water pipes must be 
separated. This is important because there is a possibility of causing accidents by trucks, which can be fatal for the mine if electrical; water and ventilation installations are in touch.

Through the ramp, the highest volume of traffic flows by trucks. The ramp can also be an evacuation exit and it is the most important path thought the mine. The next picture is an example of a ramp. The same structure of the ramp could be also found in Almina.

Picture 5. Ad isplay of the ramp

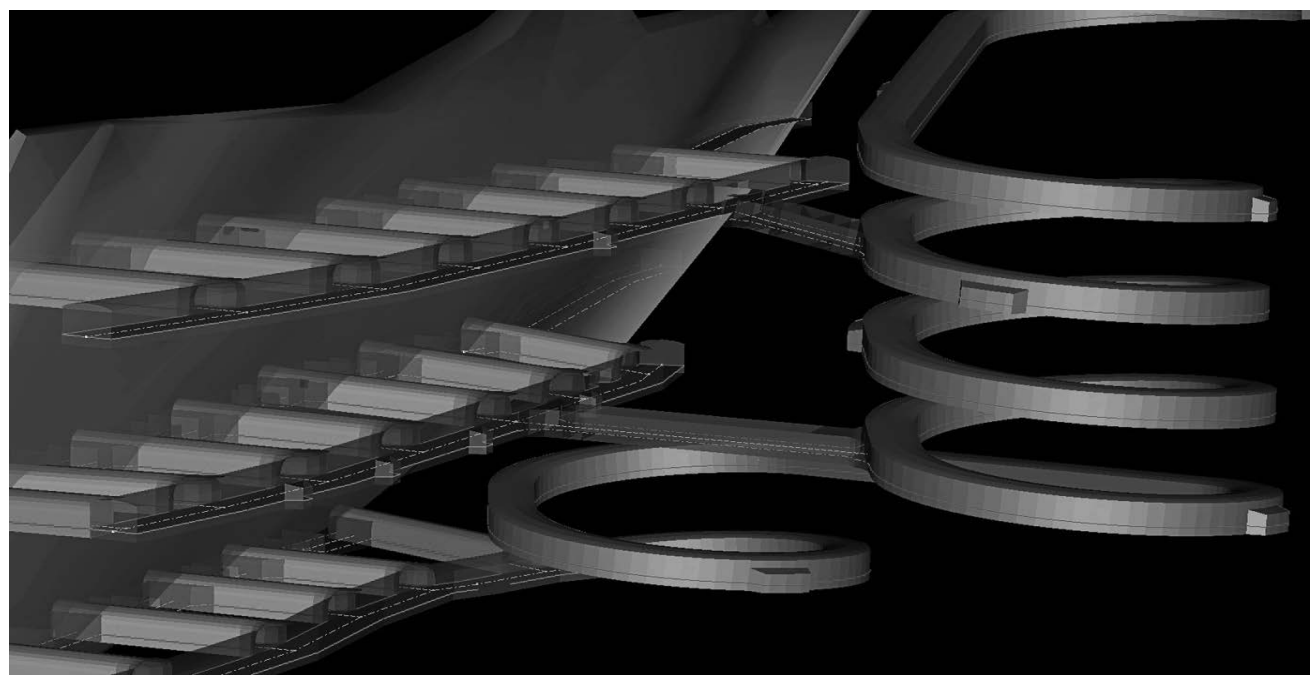

Source: http://www.camese.org/news.cfm?itemid=10898

Other paths, which are blue, represent secondary paths (or galleries), which are a connection between a ramp (red) and extraction part (green). Ventilation works through the gallery and extraction part, but only in places where people still work. In other words, ventilation will be closed in the places where the extraction stops in order to save energy.

An underground ventilation system is divided in three ways - a station with fresh air, tube dividers and tubes which supply fresh air.

A fresh air station is a place where mine companies store fresh air from the surface. Fresh air is transported by fans from the surface and stations store that fresh air. Later on, fresh air is transported by tube dividers. A fresh air station can have one or two tube suppliers and this depends on mine characteristics. The capacity of a station depends on the size of the mine, quantity of workers and other reasons. A station can experience air leaking and, for this reason, an emergency team is responsible for maintenance. Also, stations are under great pressure because of a high quantity of air from the surface. In the case of an accident, stations are used as an emergency station and they can also be emergency exits to the surface. 
M. Miličić, K. Dundović: Ventilation system in the Portuguese mining company Almina Zbornik Veleučilišta u Rijeci, Vol. 5 (2017), No. 1, pp. 89-106

Picture 6. A station with fresh air with two air tube suppliers

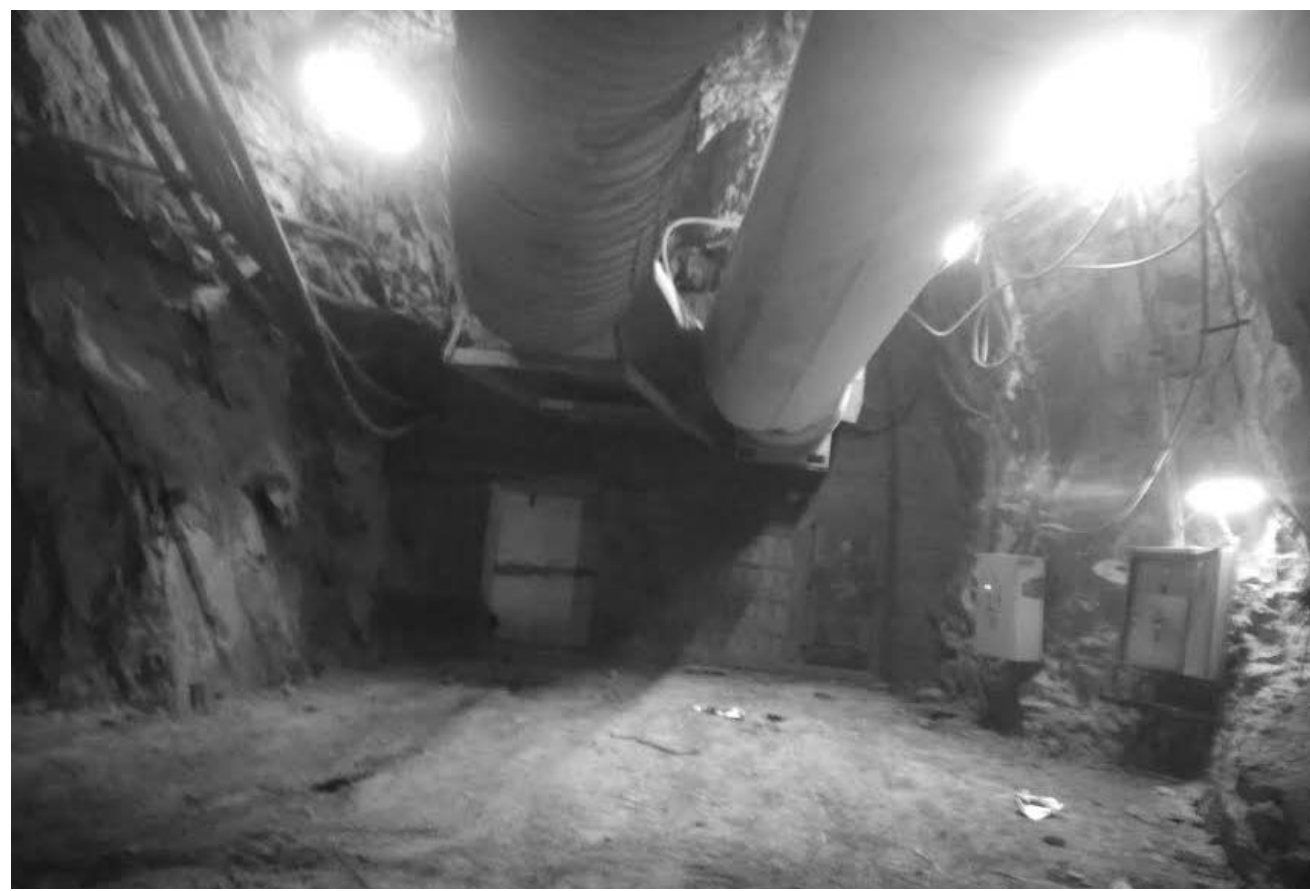

Source: Author's photo

Picture 7. A station with fresh air with one air tube supplier

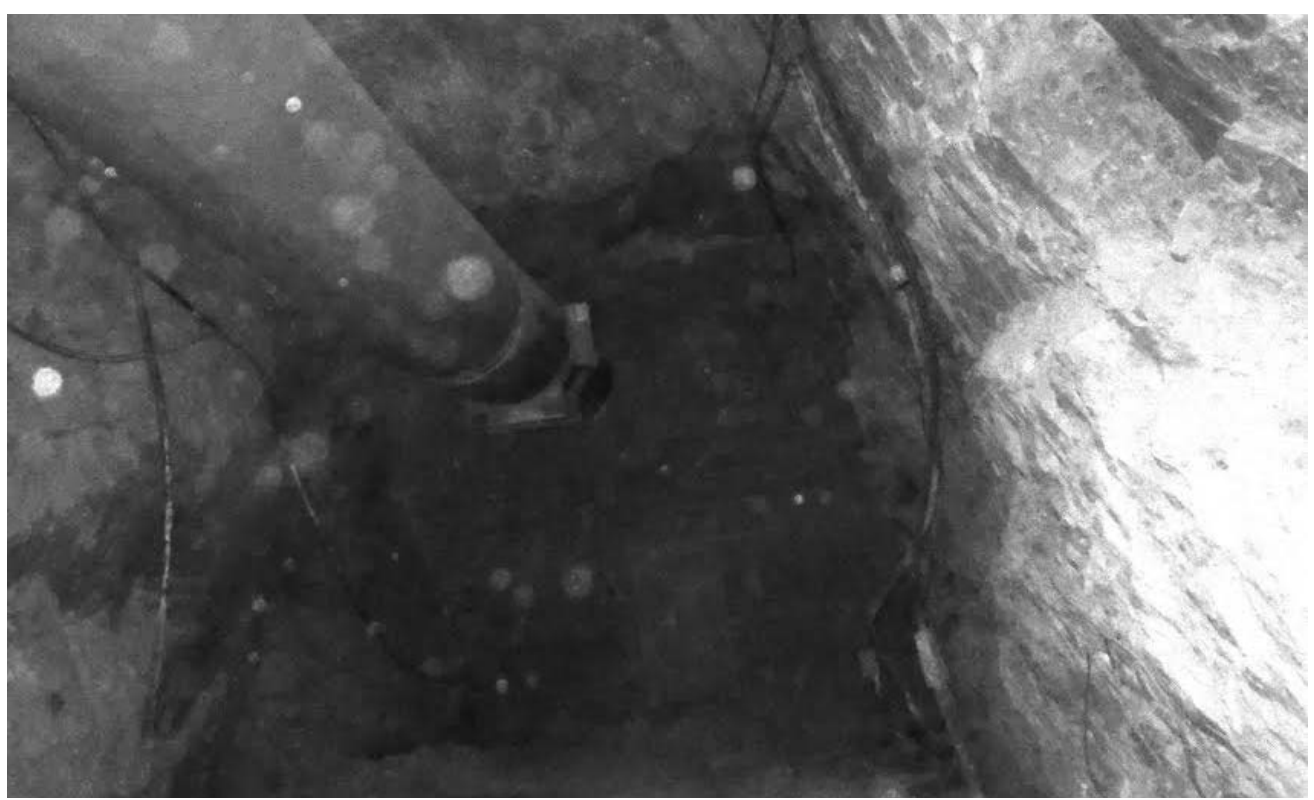


Fresh air from stations can be transported to one or more places. This process is allowed by dividers. They are made from special rubber material which is resistant in different kinds of dangerous atmosphere and it is elastic. They need to be controlled and monitored regularly. In the case of damage, they must be replaced; e.g. if a divider has a hole that leads to air leaking, the company will experience energy loss. In this case, workers need to replace a damaged divider with a new divider or fix the problem.

Picture 8. An example of one way air divider

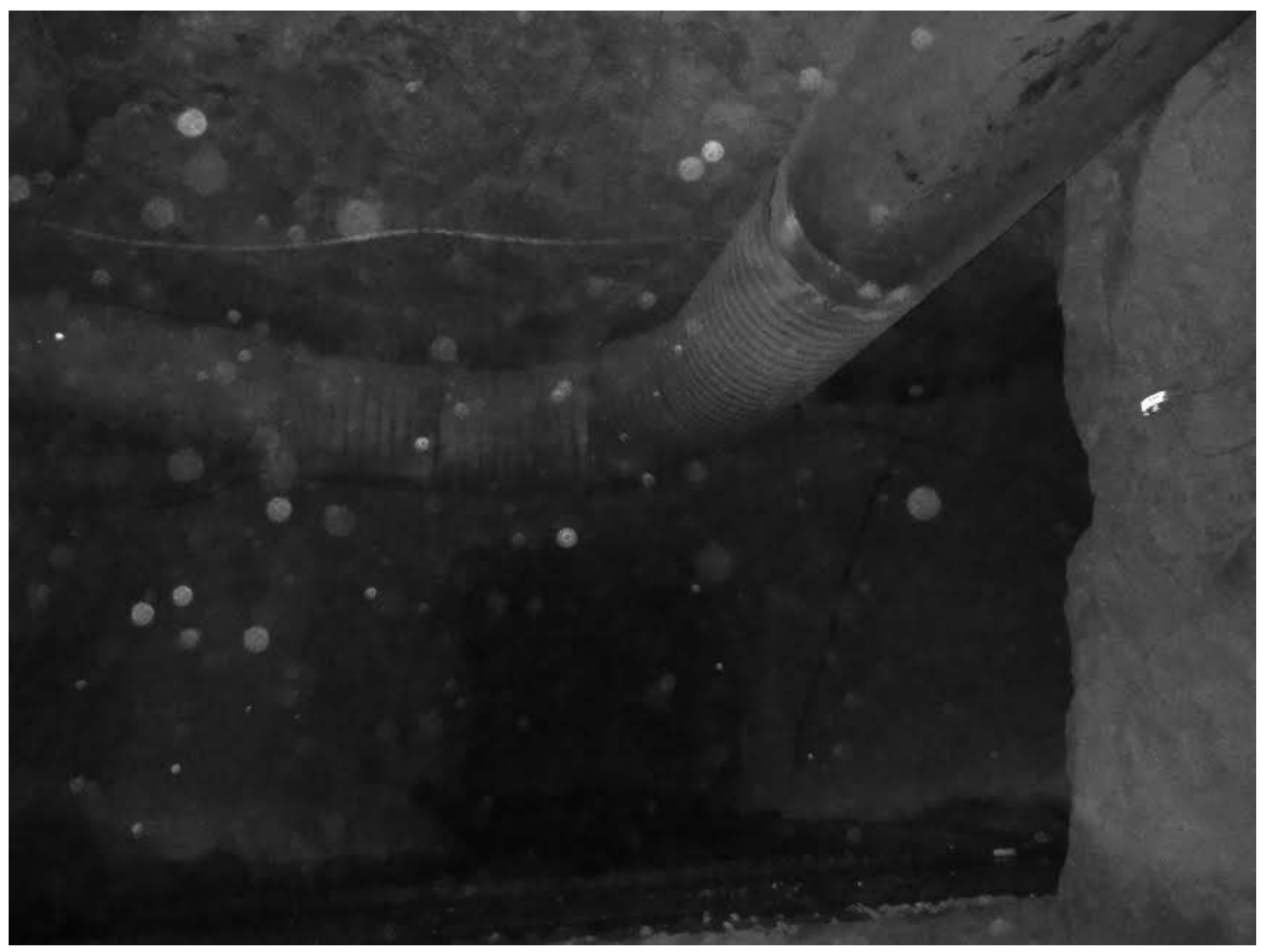

Source: Author's photo

Tubes which support fresh air are made from the same material as air dividers - elastic rubber. At the end of every air tube there is a hole which supplies air to workplaces and workers. Air tubes can have two shapes - open and closed. If they are open and in full function (air supply), they support air in the workplace or to the works. Also, they can be open, but out of function. It means that in some period ventilation will not work due to some reasons (e.g. detonation, fixing problems, temporary absence from work...). The size of the open end part is the same as a diameter of the tube. 
Picture 9. The end part of an air tube

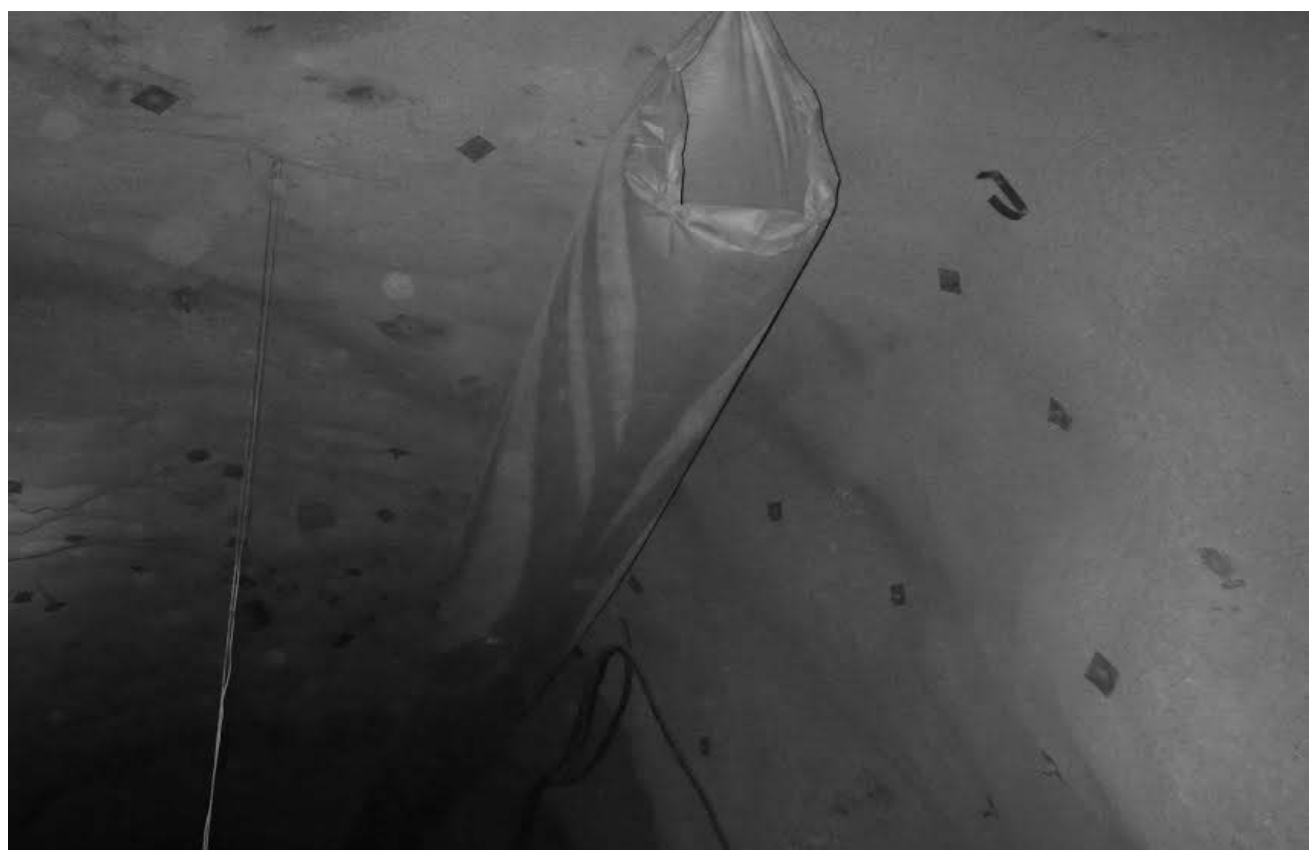

Source: Author's photo

Air tube ventilation can be closed in two ways - permanently and temporarily.

Exploration of mines can last from a few months to several years. Exploration is divided in sectors, which are supplied by fresh air. When the exploration of one part of the mine is over, ventilation must be turned off. That happens because the energy is used unnecessarily in places where there is no exploration and workers do not work there.

Furthermore, air tube ventilation can be closed temporarily due to two reasons - air tube can be damaged or because of a certain situation (e.g. detonation inside of a mine). If an air tube is damaged (e.g. it contains holes) ventilation must be shut down and repaired because air leaking means losing energy and money for the company. During detonation, ventilation is closed, given that during several hours the mine is empty and there is no need for fresh air. Also, during detonation, the atmosphere has toxic mixtures which means that fresh air is of disputable quality. 
Picture 10. An example of closed air tube

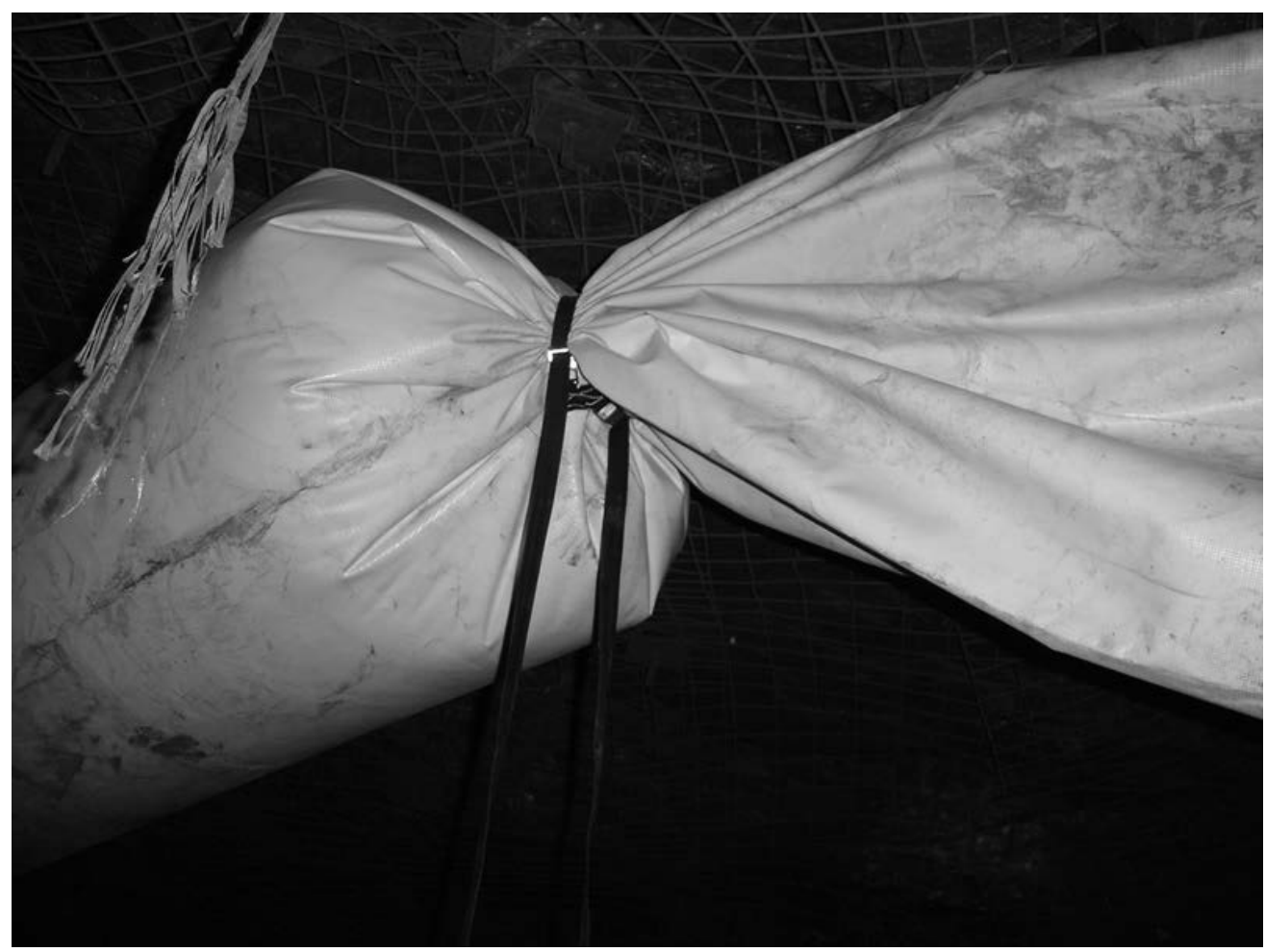

Source: http://www.rocvent.com/index.php/products/type/category/accessories

In Almina the maximum distance of air tubes from the workplace is 20 meters. It is the measure which allows normal air inhalation for normal working conditions. The end of air tube must be open and directed to the workplace, respectively, to workers. However, if the end of air tube is too close to the workplace, there is a possibility for an accident. Machines can catch an air tube and it can lead to an emergency situation. The most important thing is to find a perfect distance between workers and an air tube. 
Picture 11. An example of distance between end of open air tube and workplace

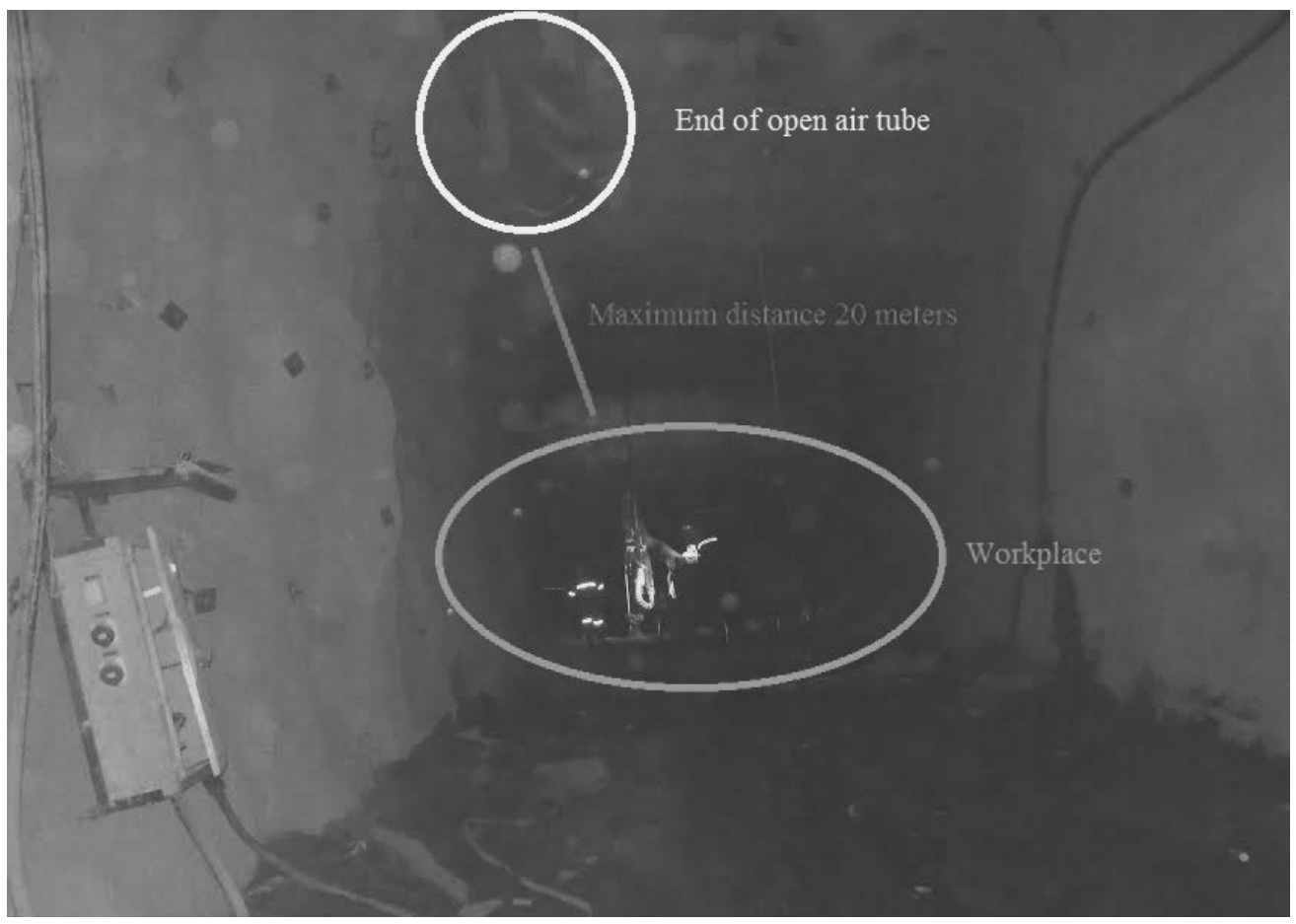

Source: Author's photo

Also, the end of an air tube can be more than 20 meters from the workplace, respectively, from workers. This situation can happen in case of an exceptional situation, such as making new exploration. During new detonation, respectively exploration, ventilation can still not be installed, but the work must go on. In this situation ventilation can be more than 20 meters from the workplace and workers, but during the process, it must be set up at a proper distance.

\section{3 A blocked main tube of a ventilation system}

The main tube is a connector between the main fan on the surface and an undergound fresh air station and it is a supplier of fresh air. The main tube has a large diameter which is made of iron and it is surrounded by ground and rocks under the ground. The main and sometimes unpredictable problem is when the ground and rocks collapse inside of the main tube. This can happen, for example, during detonation or drilling. In that moment fresh air cannot be transported inside of the mine and workers must be evacuated. According to this situation, the production of copper must stop and an emergency group must intervene, investigate the situation, see where the problem is and how to solve it. A problem can be solved in two ways: drilling rocks or detonating the explosive. 
This situation does not happen very often because the position of the ground and rocks is investigated by geologists and it is predicted to be safe. However, geologists cannot be $100 \%$ sure and they need to have an emergency plan in that situation.

\subsection{An example of ventilation profile of the mine feitais}

The Portuguese mining company Almina includes two mines - Minho and Feitais. Every mine has its own ventilation system on the surface and underground.

Feitais mine has four main fans which transport fresh air inside of the mine and four exits for stale air. Every fan has different specifications and every exit has different air permeability. Also, every tunnel has different air conductivity, which depends on the power of fans.

The next schema represents the ventilation profile of Feitais. The drawn clean air from an outside source must have a bigger quantity than removed old, stale air. In this case a ration of drawn clean air and removed stale air is $425 \mathrm{~m} 3 / \mathrm{s}: 420 \mathrm{~m} 3 / \mathrm{s}$.

Scheme 1. A ventilation profile of the mine Feitais

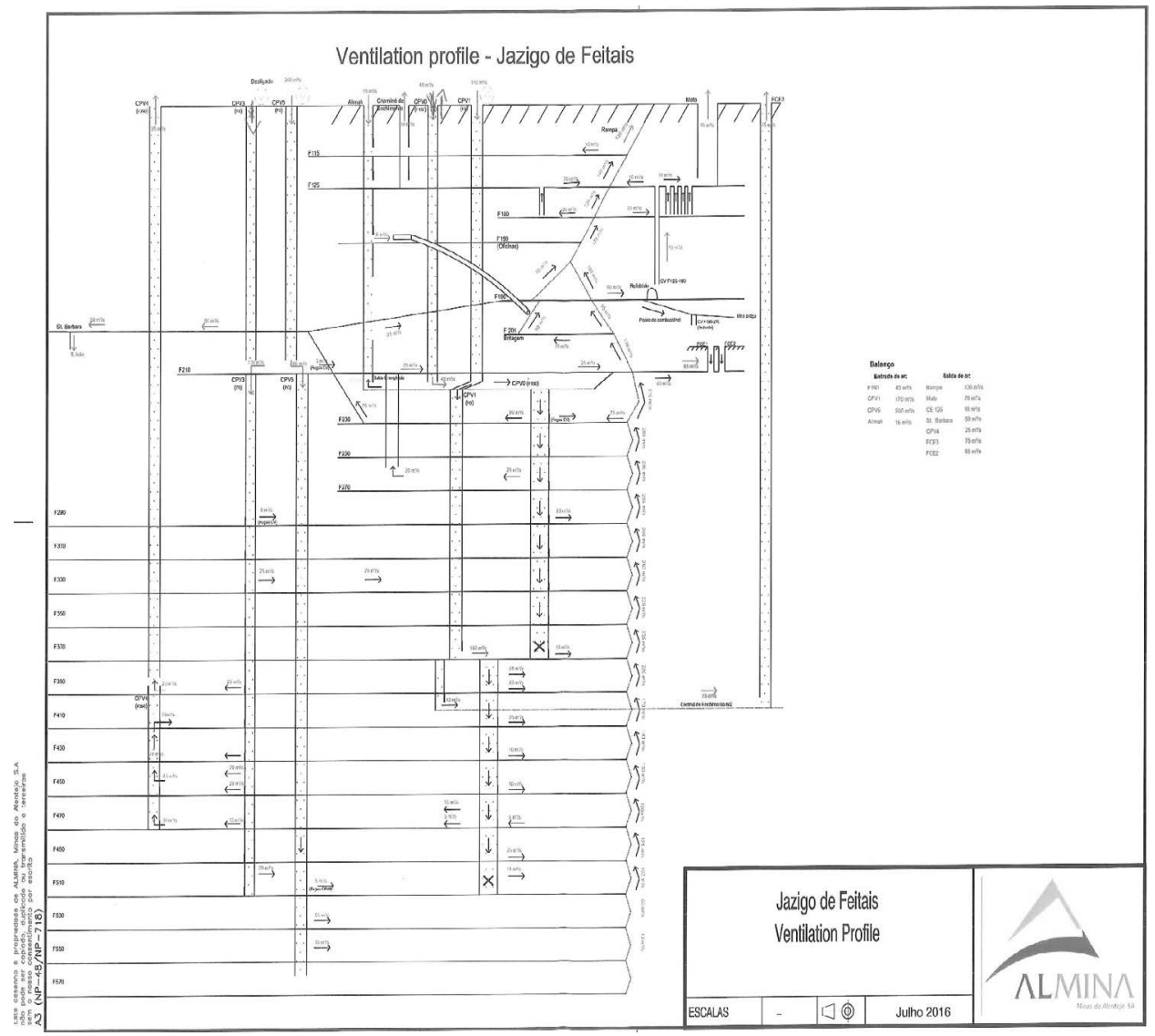




\section{RESULTS}

A ventilation system is an important part of every mining company. A balance between surface part and underground part of a ventilation system must be excellent for fresh air inhaling and exhaling.

Ventilation on the surface in Almina's company is new and equipped with modern technology. The surface ventilation part has 8 fans, which have different inhaling power (from $150 \mathrm{~m} 3 / \mathrm{s}$ and more) and different specifications. Every fan has a task to supply one part of the mine with the main tube, which includes the position, depth and inhaling power. Also, every fan is controled by an engineer who has an obligation to check a ventilation fan every working day. Problems can occur if the main fan breaks down or the main tube fills with rocks and ground.

A ventilation system under the ground is supported by 8 main fans on the surface. $A$ ventilation system under the ground consists of three parts: a fresh air station, air divider and air tube. A fresh air station stores fresh air. The same fresh air is transported by the main tube from the main fan to the surface. An air divider consists of one or two dividers, which transport fresh air to the workplace. An air tube is the main transporter of fresh air through the mine. Problems can occur if all these elements fail.

According to problems of a ventilation system, an emergency team, which is in charge of repair, must react very fast due to the following two reasons. The first reason is saving human lives. Workers under the ground may not have a feeling of running out of fresh air, and when they found out, it will maybe be too late. The second reason is economic. Every ventilation stopping means production stopping which leads to the waste of money.

Solutions for these problems are: an excellent emergency plan, every day control and a good connection between workers.

\section{CONCLUSION}

The ventilation system in the Portuguese mining company Almina operates perfectly. Both systems (surface and underground) are well-connected and during the past they did not experience many problems. The systems are controlled by educated engineers who are experienced in that job. Also, inside the mine, the quality and quantity of the air is excellent - the level of oxygen is more or less always around $20-21 \%$.

A ventilation system respresents one of the main requirements for normal working conditions. Without a ventilation system the working process, and also life, inside the mine could not be possible. In addition. the system must be regulated and controlled by workers to avoid dangerous situations.

A ventilation system is very important during evacuation and surviving. During evacuation, it is predicted that a ventilation system will turn on in places where there are safety paths. Furthermore, if workers are trapped inside the mine, a ventilation system must be regulated for places where people can survive. 
Without ventilation, the life inside the mine could not be possible. It is important to take a ventilation system of the mine seriously and access them rationally. Problems can occur in every moment so it is important to control the system.

In the future the ventilation system of Almina's mines will be more complex because the mine will develop deeper inside the ground. The system will have more components which means it will be prone to experience more risks and controls.

\section{REFERENCES}

Almina's unpublished internal document Plano de Segurança e Saúde (2015)

Cox, E. "What is Temperature? - Definition \& Measurement" // http://study.com/academy/lesson/what-is-temperaturedefinition-lesson-quiz.html (10.01.2017)

Hartman L. H. et al. (1997) Mine Ventilation and Air Conditioning - 3rd Edition, New York: Wiley

Horvatić M. (2008) English for Safety Engineers, Karlovac: Veleučilište u Karlovcu

http://miningquiz.com/powerpoints/mine_rescue.htm (10.01.2017)

http://web.mst.edu/ tien/218/218-LabSystem.pdf (10.01.2017)

http://www.almina.pt/ (10.01.2017)

http://www.infoplease.com/encyclopedia/science/ventilation.html (10.01.2017)

http://www.undergroundcoal.com.au/fundamentals/01_associated_1vent.aspx (10.01.2017)

http://www.worksafe.govt.nz/worksafe/information-guidance/all-guidance-items/ventilation-in-underground-minesand-tunnels/ventilation-mines-and-tunnels-pdf (10.01.2017)

https://www.msha.gov/ (10.01.2017)

Tumbde, A., Caldwell, J. "Ventilation“ // http://technology.infomine.com/reviews/ventilation/welcome.asp?view=full (09.01.2017) 


\section{VENTILACIJSKI SUSTAV U PORTUGALSKOJ RUDNIČKOJ TVRTKI „ALMINA“3}

\section{SAŽETAK}

Sigurnost rada u rudniku uključuje dvije glavne obaveze - stropnu i podnu potporu te ventilacijsku potporu. Stropna i podna potpora važne su jer u slučaju nesreće radnici mogu bez poteškoća evakuirati rudnik. No za normalne radne uvjete unutar rudnika, osim stropne i podne potpore, značajan je i ventilacijski sustav, ključ svakog radnog procesa. U radu je predstavljen ventilacijski sustav portugalske rudničke tvrtke "Almina". Rad prikazuje ventilacijski sustav na površini zemlje te sustav ispod površine zemlje. Prikazani su glavni problemi ventilacijskog sustava, kao i sheme upuhivanja svježeg zraka te ispuhivanje ustajalog zraka izvan rudnika. Rezultat rada je shvaćanje funkcioniranja ventilacijskog sustava u praksi. Cilj rada je prezentirati ventilacijski sustav u praksi s obzirom na to da u Republici Hrvatskoj ne postoje rudničke tvrtke gdje bi ljudi mogli naučiti činjenice o rudnicima i ventilacijskom sustavu, što može biti vrlo značajno u slučajevima kada prijete opasne situacije.

Ključne riječi: rudnik, sigurnost u rudniku, ventilacijski sustav, problemi s ventilacijom, radni uvjeti

Bacc. ing. sec., student, Veleučilište u Rijeci, Vukovarska 58, Rijeka, Croatia. E-mail: mario.milicic.1993@gmail.com Dipl. ing. sig., predavač, Veleučilište u Rijeci, Vukovarska 58, Rijeka, Croatia. E-mail: kristina.dundovic@veleri.hr Datum primitka rada: 15. 1. 2017; datum prihvaćanja rada: 15. 2. 2017. 